\title{
PERANCANGAN APLIKASI OLAP MENGGUNAKAN METODE CLUSTERING UNTUK ANALISIS DATA SIMPAN PINJAM ANGGOTA PADA KSP RIAS MUSI RAWAS
}

\author{
Ahmad Sobri \\ Program Studi Informatika, Universitas Bina Insan, Lubuklinggau \\ e-mail: ahmadsobri@univbinainsan.ac.id
}

\begin{abstract}
Abstrak
Penelitian dilakukan untuk Aplikasi hanya membahas tentang analisis data simpanan dan pinjaman anggota pada KSP RIAS Musi Rawas. Selain itu merancang dan mengimplementasikan aplikasi manajemen data OLAP untuk analisis data anggota untuk memudahkan pihak manajemen dalam menyediakan berbagai jenis informasi yang dapat mendukung dalam pengambilan keputusan strategi. Dan juga menganalisa dan mencoba membuat program manajemen data OLAP dengan menggunakan bahasa pemrograman PHP dan MYSQ. Pada penelitian ini bagian dari rancang bangun dibuat sesuai dengan pengunaan sistem secara online untuk melakukan transaksi simpan pinjam yang sesuai dengan kode atau urutan pada kartu anggota koperasi. Metode Clustering akan mempermudah nasabah dalam melihat saldo simpanan yang terdapat pada aplikasi OLAP sehingga dapat menaikkan simpanannya.
\end{abstract}

Kata Kunci : OLAP; Metode Clustering.

\begin{abstract}
The research was conducted for applications only to discuss the analysis of data on savings and loans members at KSP RIAS Musi Rawas. In addition, designing and implementing OLAP data management applications for member data analysis to facilitate management in providing various types of information that can support strategic decision making. And also analyze and try to create an OLAP data management program using the PHP programming language and MYSQ. In this study, part of the design is made in accordance with the use of an online system to make savings and loan transactions in accordance with the code or sequence on the cooperative member card. The clustering method will make it easier for customers to see the savings balance contained in the OLAP application so that they can increase their savings.
\end{abstract}

Keywords: OLAP; Clustering Method

\section{PENDAHULUAN}

Perkembangan teknologi yang sedemikian cepat menimbulkan berbagai fenomena diberbagai dunia usaha. Perkembangan dunia usaha semakin meningkat ditunjang dengan perkembangan komunikasi yang mempermudah organisasi atau perusahaan untuk mengakses data, sehingga mengubah manajemen basis data menjadi manajemen basis data tingkat lanjut didukung dengan fasilitas data warehousing dan fasilitas basis data berbasis web sebagai salah satu strategi organisasi dalam meningkatkan kinerja dan keuntungan organisasi.
Perancangan sistem adalah tahap yang dilakukan setelah melakukan analisis sistem, pendefinisian kebutuhan-kebutuhan sistem yang akan dibangun, dan persiapan untuk merancang bangun implementasi sistem dengan menggambarkan sistem yang akan dibangun. Perancangan sistem dimulai dengan memahami sistem yang sedang berjalan dan kriteria-kriteria sistem yang akan dibangun biasanya menggunakan pemodelan secara terstruktur yang digambarkan oleh grafik atau diagram. [1]

Dalam meningkatkan jumlah nasabah atau konsumen pada koperasi KSP"RIAS" ini maka harus dapat menggunakan beberapa promosi agar nasabah bias 
mengetahui dan juga dapat informasi tentang simpan pinjam pada koperasi. Dalam meningkatkan promosi di koperasi karyawan dapat melakukan kerjasama lagi dengan instansi yang ada di kabupaten Musi Rawas dan juga kota kota yang terdekat dengan lokasi koperasi KSP" RIAS" untuk mempermudah kosnumen dalam meminjam uang di koperasi ini.

Selama ini koperasi simpan pinjam"RIAS" melakukan promosi hanya melalui mulut ke mulut dari konsumen yang telah menlakukana pinjam, agar nasabah atau konsumen dapat meningkat maka perlu diadakan promosi secara online atau melakukan promosi dengan bantuan media social. Tetapi permasalah yang dihadapi oleh koperasi simpan pinjam KSP"RIAS" terkendala dengan system yang belum ada.[2]

KSP "RIAS" P2. Mardiharjo didirikan pada tanggal 12 Agustus 1985, sebagai Koperasi Primer, yang bergerak pada usaha simpan - pinjam diantara para anggotanya. Pada awalnya bernama Kopdit "RIAS", yaitu Koperasi Kredit Rukun Iku Agawe Santoso, dibina oleh Puskopdit Handriya Sanggraha Palembang hingga sekarang. Hidup dan berkembang secara sederhana mulai tanggal 12 Agustus 1985 hingga 30 Januari 2001. Karena dikelola dan dengan sistem tradisional, maka anggotanya datang dan pergi, serta dengan simpanan wajib yang kecil sehingga saham dan permodalan kurang memenuhi kebutuhan anggota.Pada tanggal 30 Januari 2001, nama Kopdit "RIAS" berganti menjadi KSP "RIAS", seiring dengan terbitnya Badan Hukum dari Dinas Perindagkop Kab. Mura Nomor: 00219/BH/VI.7 tanggal 5 Januari 2001. Dengan Badan Hukum tersebut KSP "RIAS" memasuki babak baru dalam pengelolaan simpan pinjamnya, yaitu dengan sistem manajer dan karyawan.
Sistem yang berjalan pada KSP Rias sebagian besar sudah menggunakan komputer untuk mengelola data dalam proses bisnisnya. Untuk saat ini data hasil kegiatan operasional pada unit simpan pinjam sudah disimpan dalam database yang disediakan oleh sistem informasi koperasi, yang terdiri dari data transaksi simpanan dan data transaksi pinjaman. Permasalahan yang terjadi saat ini adalah desain data dari data operasional koperasi yang sulit untuk diubah menjadi informasi yang dibutuhkan, dikarenakan masingmasing sumber data memiliki struktur dan format yang berbeda. Kesulitan lainnya adalah kesulitan dalam menganalisis laporan periodik harian, bulanan dan tahunan, seperti laporan simpanan, dan pinjaman anggota. Kesulitan tersebut dikarenakan laporan yang ada tidak dapat menampilkan informasi dari berbagai kategori proses bisnis koperasi atau multidimensi, dan tidak adanya media untuk menganalisis dan membuat laporan yang dapat disesuaikan dengan kebutuhan bisnis, seperti halnya dalam menganalisis laporan simpanan anggota yang berdasarkan kategori nama simpanan atau nama cabang dalam periode tertentu. Dampak dari permasalahan yang terjadi yaitu mengakibatkan waktu yang dibutuhkan untuk mengambil suatu keputusan bisnis menjadi terhambat dikarenakan lamanya akses terhadap data dan informasi yang dibutuhkan.

Dari permasalahan yang ada di KSP "RIAS" Musi Rawas, dibutuhkan sebuah sistem yang mampu menangani masalah tersebut dengan membuatkan ringkasan data operasional yang berorientasi pada topik yang diinginkan pihak manajemen KSP Rias, yakni perihal menganalisis tingkat simpanan dan pinjaman dari anggota sehingga mampu memberi kemudahan bagi pihak manajemen untuk 
mendapatkan informasi strategis dari sumber data yang ada.

\section{TINJAUAN PUSTAKA}

\subsection{Pengertian Perancangan.}

Perancangan sistem adalah tahap yang dilakukan setelah melakukan analisis sistem, pendefinisian kebutuhan-kebutuhan sistem yang akan dibangun, dan persiapan untuk merancang bangun implementasi sistem dengan menggambarkan sistem yang akan dibangun. Perancangan sistem dimulai dengan memahami sistem yang sedang berjalan dan kriteria-kriteria sistem yang akan dibangun biasanya menggunakan pemodelan secara terstruktur yang digambarkan oleh grafik atau diagram[1].

\subsection{Defenisi Aplikasi}

Aplikasi merupakan penerapan, menyimpan sesuatu hal, data permasalahan, pekerjaan kedalam suatu sarana atau media yang digunakan untuk menerapkan atau mengimplementasika hal atau permasalahan tersebut sehinggga berubah menjadi bentuk yang baru tanpa meenghilangkan nilai-nilai dasar hal, data, permasalahan atau pernasalahan atau pekerjaan. Jadi dalam hal ini hanya bentuk dari tampilan data yang berubah, sedangkan isi yang termuat dalam data tersebut tidak mengalami perubahan. Jadi program aplikasi adalah sederetan kode yang digunakan untuk mengatur komputer supaya dapat melakukan pekerjaan sesuai dengan keinginan programmer atau user. Atau definisi lain aplikasi merupakan kumpulan dari prosedur-prosedur yang digunakan untuk mengolah data menjadi informasi. Misalnya penjumlahan, klasifikasi, rotasi, koreksi geometri, query, overlay, buffer, jointable dan sebagainya..[2].

\subsection{OLAP (Online Analytical Processing) \\ Data warehouse adalah sebuah basis} data yang mewakili sejarah bisnis dari suatu perusahaan atau organisasi yang berisikan data historis.

Data warehouse menyimpan data dari berbagai sumber dan sifatnya tidak membuat data baru, data yang disimpan di dalam data warehouse sering diolah sebelum disajikan untuk end-user, misalnya diringkas sebelum dicetak dalam bentuk laporan. Data yang terdapat pada data warehouse diatur sedemikian rupa sehingga dapat mendukung analisa. OLAP, atau Online Analytical Processing adalah teknologi yang mengolah informasi dari data warehouse dalam struktur multidimensi, menyediakan jawaban yang cepat untuk query(memanggil data) analisis yang kompleks. Tujuan dari OLAP adalah mengorganisir sejumlah data yang besar agar bisa dianalisis dan dievaluasi dengan cepat[3].

\subsection{Fungsi Data Warehouse}

Fungsi utama data warehouse adalah mengambil data, termasuk data eksternal; misalnya daftar kode pos dari kantor pos atau kode kepala telepon, untuk dikumpulkan, disiapkan termasuk merubah struktur dengan pembersihan dan integrasi. Data warehouse menyimpan dan menyediakan data untuk aplikasi yang sifatnya query atau membentuk laporan ikhtisar yang selanjutnya dimanfaatkan dalam analisis informasi dan sebagai pendukung pembuatan keputusan (analytical application).[3].

\subsection{Metode Cluster.}

Clustering terhadap data adalah suatu proses untuk mengelompokkan sekumpulan data tanpa suatu atribut kelas yang telah didefinisikan sebelumnya, berdasarkan pada prinsip konseptual clustering yaitu 
memaksimalkan dan juga meminimalkan kemiripan intra kelas. Misalnya, sekumpulan obyek-obyek komoditi pertama-tama dapat di clustering menjadi sebuah himpunan kelas-kelas dan lalu menjadi sebuah himpunan aturan-aturan yang dapat diturunkan berdasarkan suatu klasifikasi tertentu.

Proses untuk mengelompokkan secara fisik atau abstrak obyek-obyek ke dalam bentuk kelas-kelas atau obyek-obyek yang serupa, disebut dengan clustering atau unsupervised classification. Melakukan analisa dengan clustering, akan sangat membantu untuk membentuk partisi-partisi yang berguna terhadap sejumlah besar himpunan obyek dengan didasarkan pada prinsip "divide and conquer" yang mendekomposisikan suatu sistem skala besar, menjadi komponen-komponen yang lebih kecil, untuk menyederhanakan proses desain dan implementasi[4].

\subsection{Koperasi}

Koperasi mempunyai pengertian sebagai berikut: "Koperasi 10 adalah badan hukum yang didirikan oleh orang perseorangan atau badan hukum koperasi, dengan pemisahan kekayaan para anggotanya sebagai modal untuk menjalankan usaha, yang memenuhi aspirasi dan kebutuhan bersama di bidang ekonomi, sosial, dan budaya sesuai dengan nilai dan prinsip koperasi." Jadi dapat diartikan koperasi merupakan kumpulan orang dan bukan kumpulan modal. Koperasi harus betul-betul mengabdi kepada kepentingan perikemanusiaan semata-mata dan bukan kepada kebendaan. Kerjasama dalam koperasi didasarkan pada rasa persamaan derajat, dan kesadaran para anggotanya. Koperasi merupakan wadah demokrasi ekonomi dan sosial. Koperasi adalah milik bersama para anggota, pengurus maupun pengelola. Usaha tersebut diatur sesuai dengan keinginan para anggota melalui musyawarah rapat anggota. Pengertian ini disusun tidak hanya berdasar pada konsep koperasi sebagai organisasi ekonomi dan sosial tetapi secara lengkap telah mencerminkan norma-norma dan kaidah-kaidah yang berlaku bagi bangsa Indonesia[7]

\section{METODOLOGI PENELITIAN}

\subsection{Metode Pengembangan Sistem}

Metode pengembangan sistem yang digunakan dalam penelitian ini yaitu menggunakan metode air terjun (waterfall). Model air terjun (waterfall) sering juga disebut model sekuensial linier (sequential linier) atau alur hidup klasik (Classic life cycle). Model air terjun menyediakan pendekatan alur hidup pengangkat lunak secara sekuensial atau terurut dimulai dari analisis, desain, pengodean, pengujian, dan pemeliharaan (maintenance).

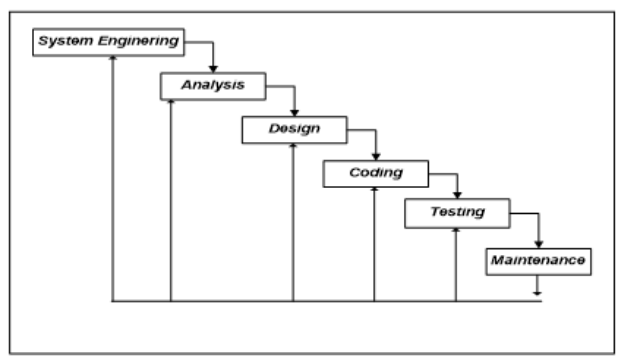

Gambar 1 Waterfall

Berikut merupakan tahap pengembangan sistem meliputi :

1. Analisis Perangkat Lunak

Proses analisis yang dilakukan penulis adalah menganilis kebutuhan sistem untuk membangun aplikasi manajemen data OLAP untuk analisis data simpanan dan peminjam pada Koperasi KSP Rias.

2. Desain (Design)

Pada tahap ini penulis melakukan desain atau perancangan aplikasi manajemen data OLAP untuk analisis data simpanan dan peminjam pada Koperasi 
KSP Rias, dalam hal ini penulis menggunakan UML

a Use Case Diagram.

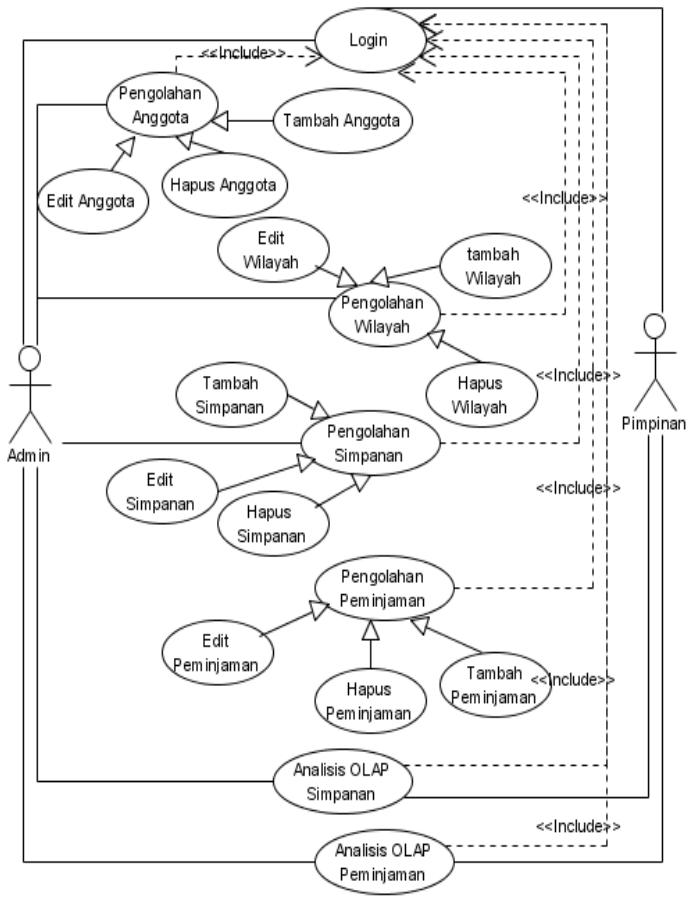

Gambar 2 Use Case Diagram

b Activity Diagram.

Activity Diagram merupakan bagian dari penggambaran sistem secara fungsional menjelaskan proses-proses logika atau fungsi yang terimplementasi oleh kode program.

\section{1) Diagram Activity Login.}

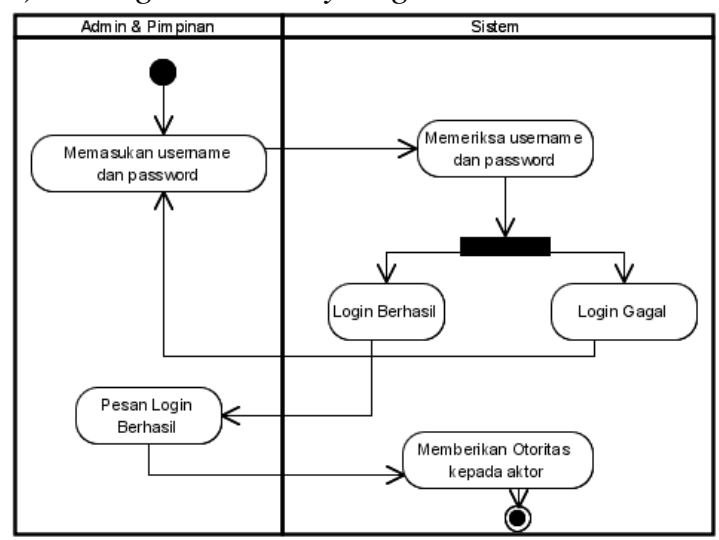

Gambar 3 Diagram Activity Login
2) Diagram Activity Pengolahan Data Anggota.

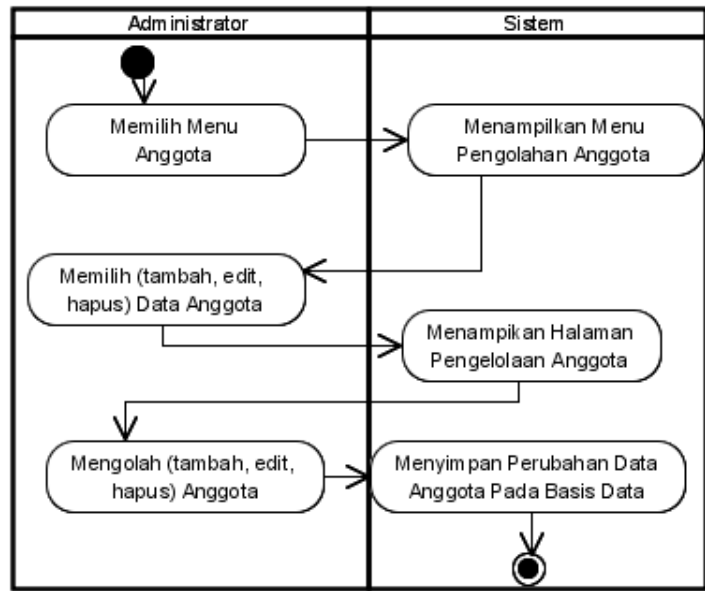

Gambar 4 Pengolahan Data Anggota

3) Diagram Activity Pengolahan Wilayah

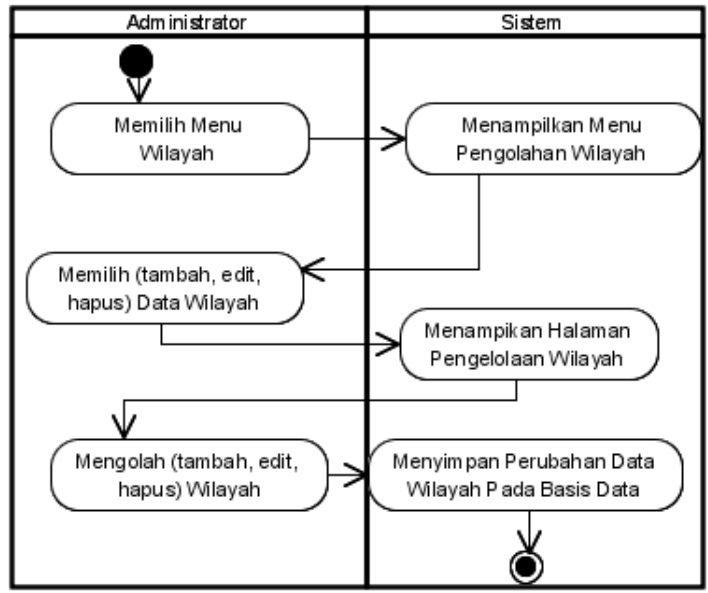

Gambar 5 Pengolahan Wilayah.

4) Diagram Activity Pengolahan Data Simpanan

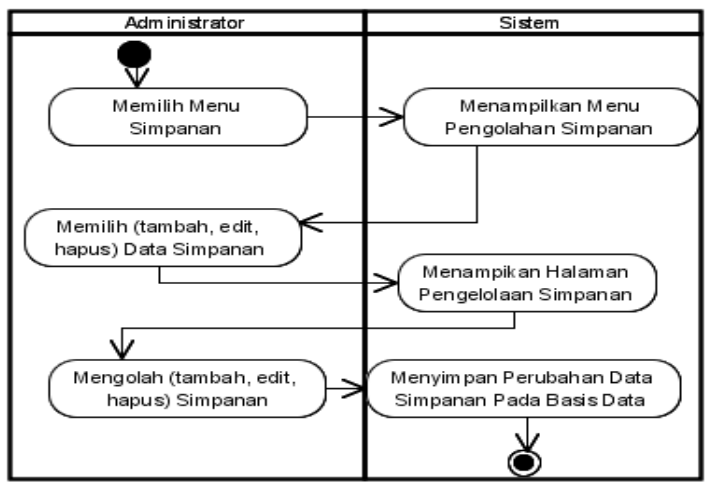

Gambar 6 Pengolahan Data Simpanan 
5) Diagram Activity Pengolahan Data Pinjaman.

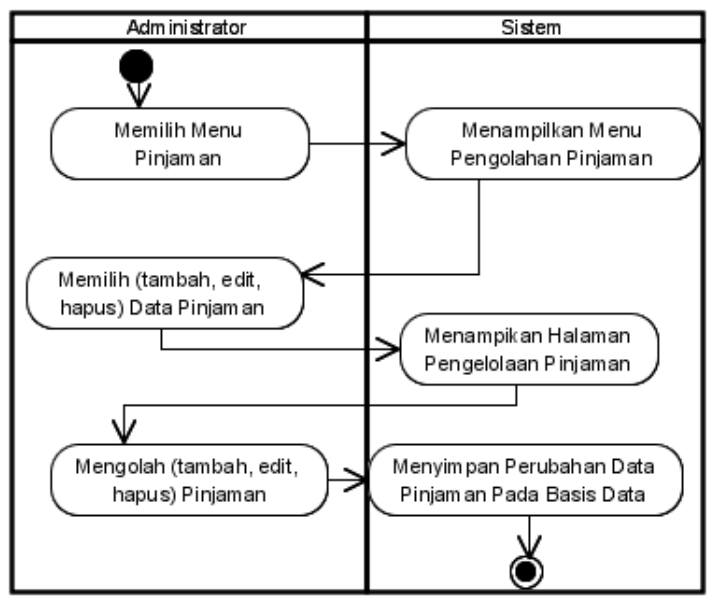

Gambar 7 Pengolahan Data Pinjaman

c Squence Diagram

1) Squence Login

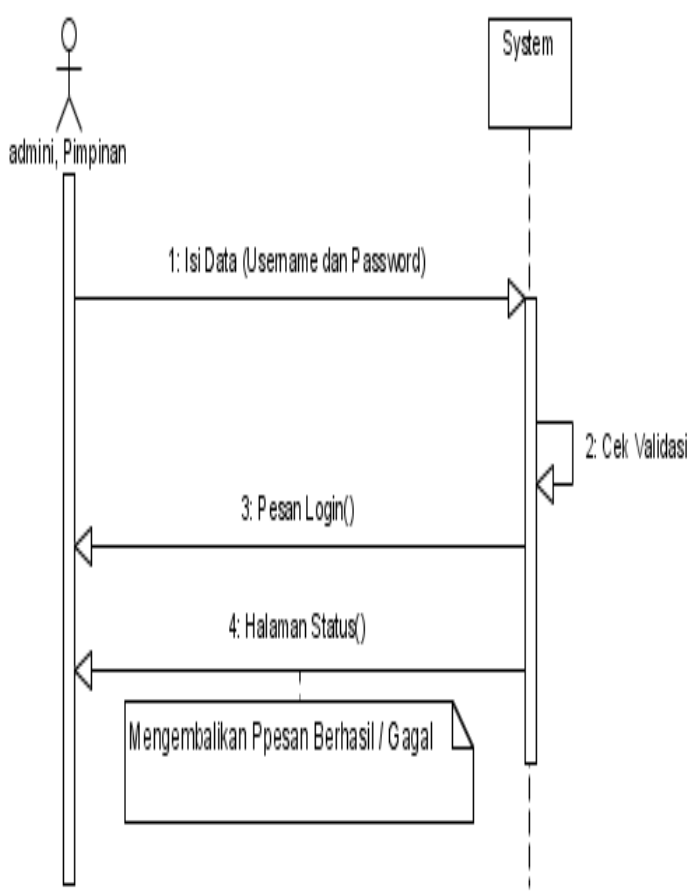

Gambar 8 Squence Login
2) Squence Pengolahan Data Anggota

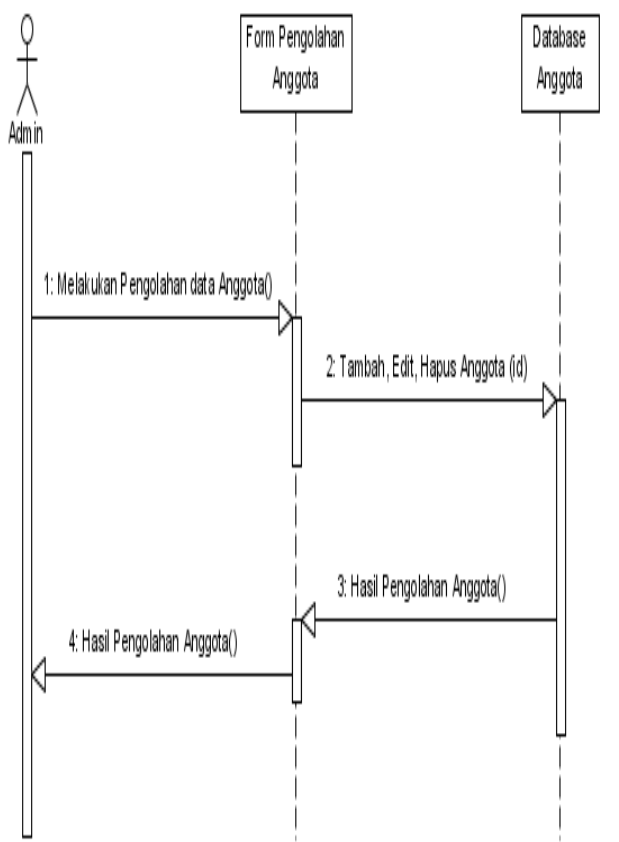

Gambar 9 Squence Data Anggota

3) Squence Diagram Pengolahan Data Wilayah.

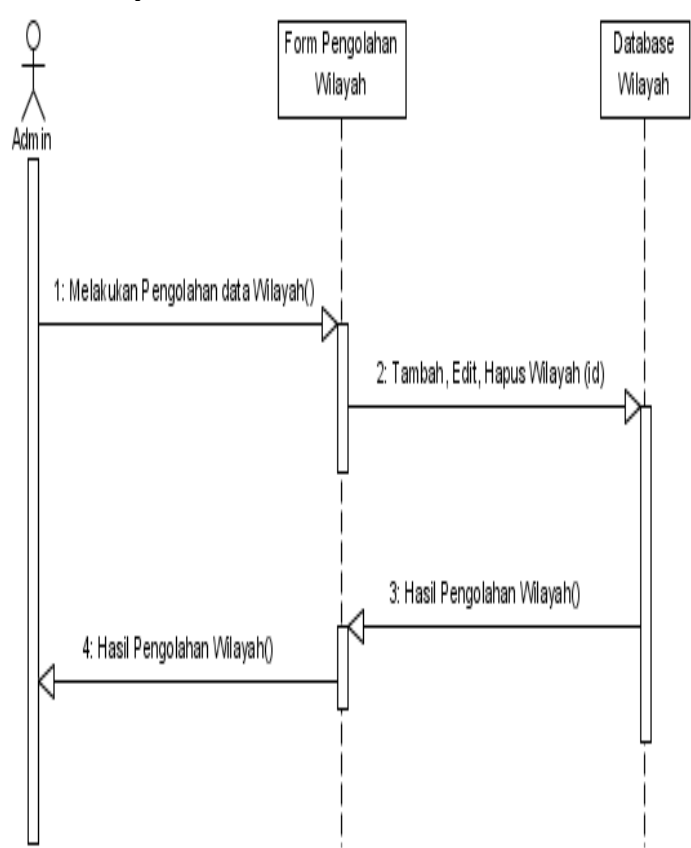

Gambar 10 Squence Pengolahan Data Wilayah 
4) Squence Diagram Lihat Analisis OLAP Simpanan.

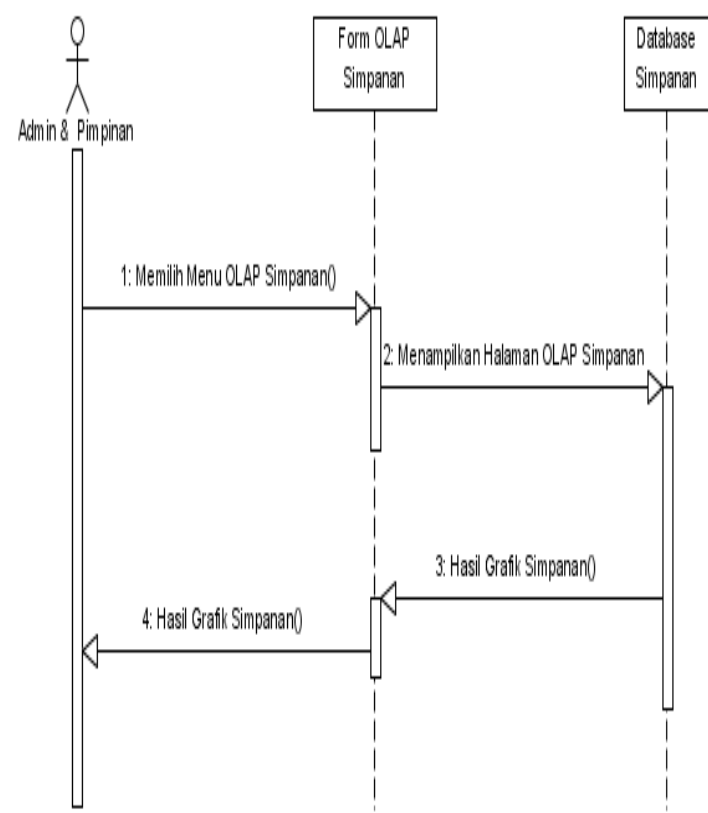

Gambar 11 Squence Pengolahan Simpanan.

5) Sequence Diagram Lihat Analisis OLAP Pinjaman.

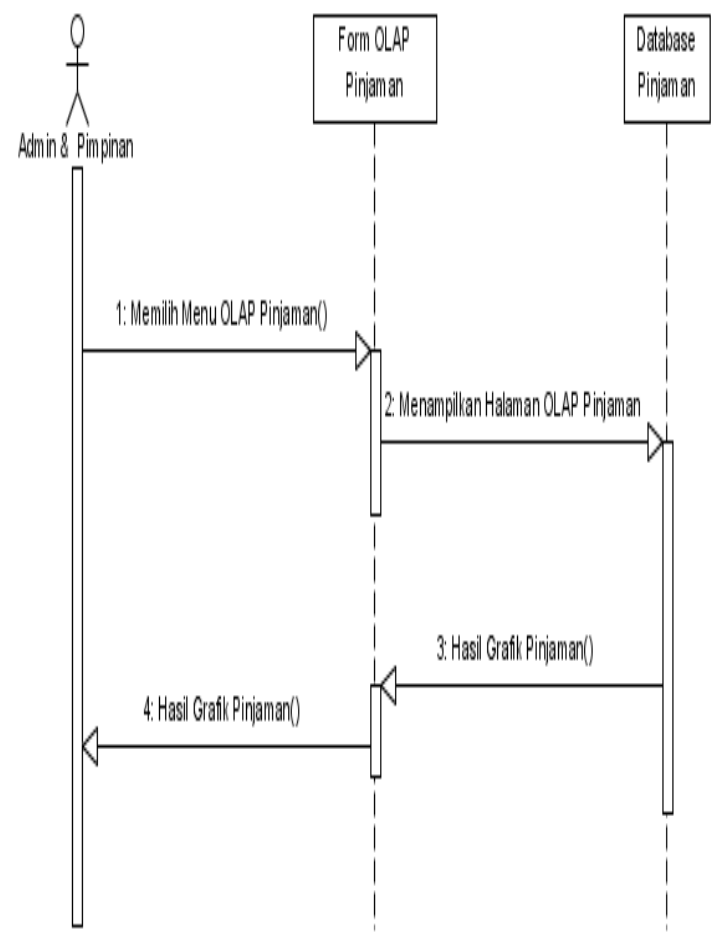

Gambar 12 Squence Pengolahan Pinjaman. d Class Diagram

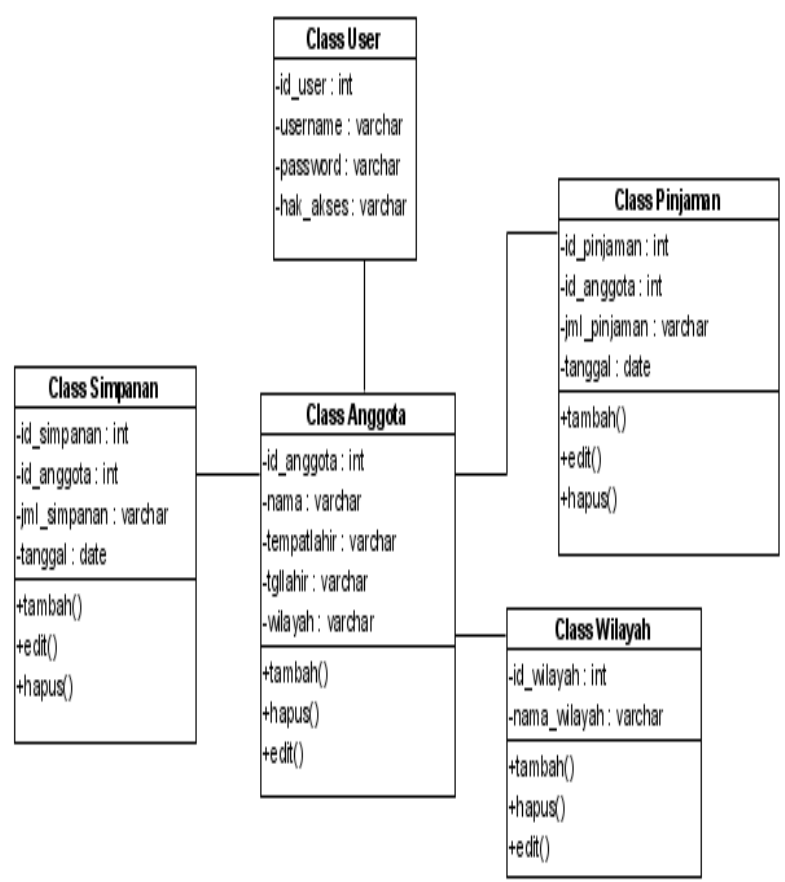

Gambar 13 Class Diagram

3. Pembuatan Kode Program (Coding)

Pada tahap ini dilakukan proses coding atau pembuatan program aplikasi manajemen data OLAP untuk analisis data simpanan dan peminjam pada Koperasi KSP Rias menggunakan PHP berdasarkan rancangan desain yang telah dilakukan pada tahap sebelumnya.

\section{Pengujian (Testing)}

Pada Tahap ini dilakukan pengujian aplikasi manajemen data OLAP untuk analisis data simpanan dan peminjam pada Koperasi KSP Rias yang sudah di coding mengngunakan metode Black Box Testing.

5. Pemeliharaan(Maintenance )

Dan setelah aplikasi manajemen data OLAP untuk analisis data simpanan dan peminjam pada Koperasi KSP Rias dilakukan testing atau diuji saatnya di implementasikan dan selama tiga bulan kedepan akan di lakukan pemeliharaan program 


\subsection{Teknik Pengumpulan Data}

Teknik pengumpulan data dapat dilakukan dengan berbagai cara. Idi antaranya sebagai berikut [9] :

1) Observasi, adalah kegiatan pengumpulan data dengan melakukan penelitian langsung terhadap kondisi lingkungan objek penelitian yang mendukung kegiatan penelitian, sehingga didapat gambaran secara jelas tentang kondisi objek penelitian tersebut.

2) Dokumentasi, yaitu pengumpulan data mengenai hal-hal atau variabel yang berupa catatan, transkip, buku, surat kabar, majalah, prasasti, notulen rapat, agenda dan sebagainya. Teknik pengumpulan ini digunakan dalam rangka mendukung teori dan data yang diperoleh baik melalui observasi maupun kuisioner.

3) Kuisioner, merupakan teknik pengumpulan data dengan cara membagikan kuisioner kepada pihakpihak yang bersangkutan dalam penelitian.

Dalam penelitian ini menggunakan teknik-teknik pengumpulan data untuk memperoleh dan mengumpulkan data melalui observasi, dokumentasi, dan angket kuisioner.

\section{HASIL DAN PEMBAHASAN \\ 1 Halaman Home.}

Halaman home adalah halaman yang pertama kali masuk kepada aplikasi OLAP.

\section{OLAP SIMPAN PINJAM DAN ANGGOTA} KSP. RIAS MUSI RAWAS

\section{Halaman Login Admin.}

Halaman login admin adalah halaman untuk autentifikasi user administrator untuk masuk kehalamannya.

\section{Login Administrator}

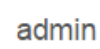

\section{Log in}

Gambar 15 Login Admin

\section{Halaman Home Administrator}

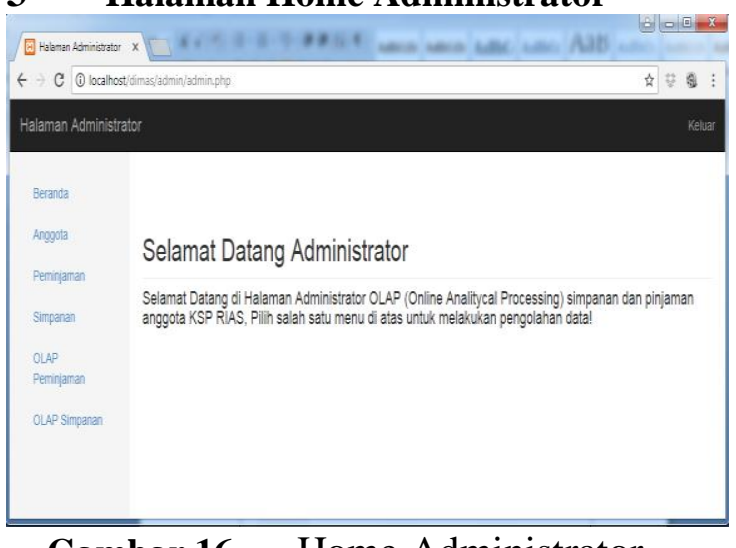

Gambar 16 Home Administrator

\section{Pengolahan Anggota.}

Pada halaman kami akan di tampilkan jika user administrator melakukan eksekusi pada menu Anggota, pada menu ini akan di tampilkan halaman untuk pengolahan data anggota baik itu penambahan data anggota, pengeditan dan penghapusan data anggota.

\section{Gambar 14 Halaman Home}




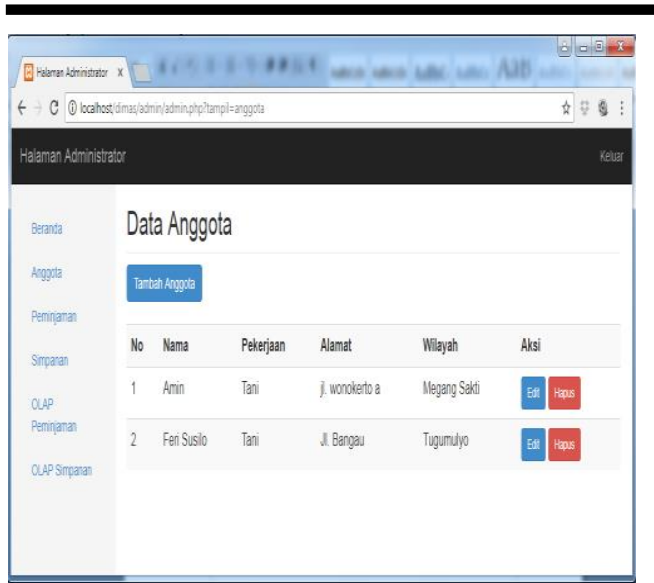

Gambar 17 Halaman Pengolahan Anggota

\section{Halaman Pengolahan Peminjam.}

Pada halaman kami akan di tampilkan jika user administrator melakukan eksekusi pada menu Peminjaman, pada menu ini akan di tampilkan halaman untuk pengolahan data peminjaman.

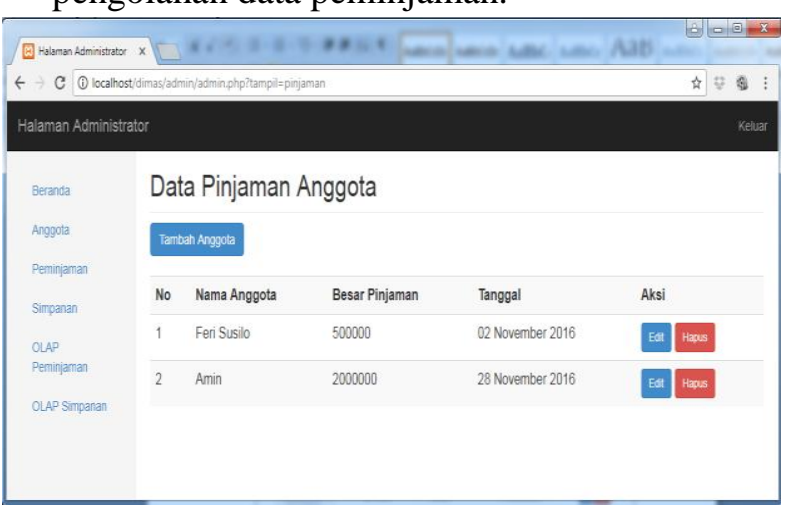

Gambar 18 Pengolahan Peminjam

\section{Halaman Pengolahan Simpanan.}

Pada halaman kami akan di tampilkan jika user administrator melakukan eksekusi pada menu simpanan, pada menu ini akan di tampilkan halaman untuk pengolahan data simpanan.

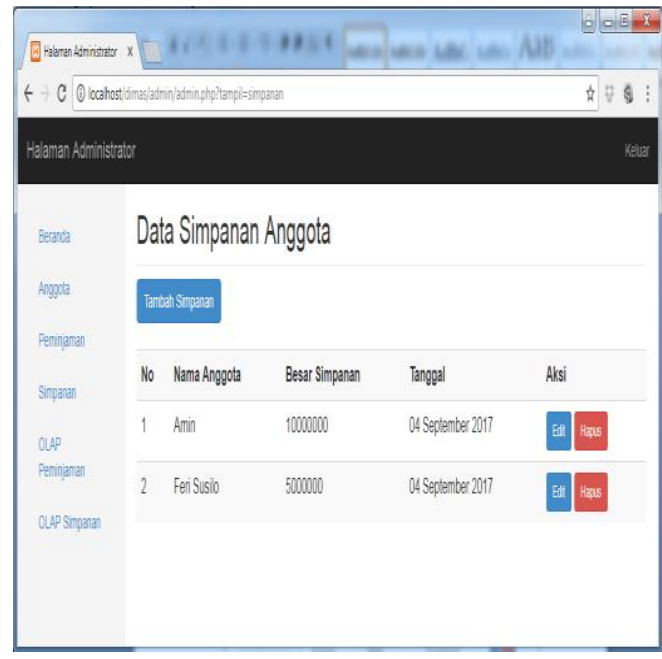

Gambar 19 Pengolahan Simpanan

7 Halaman Pengolahan Laporan Data Simpanan.

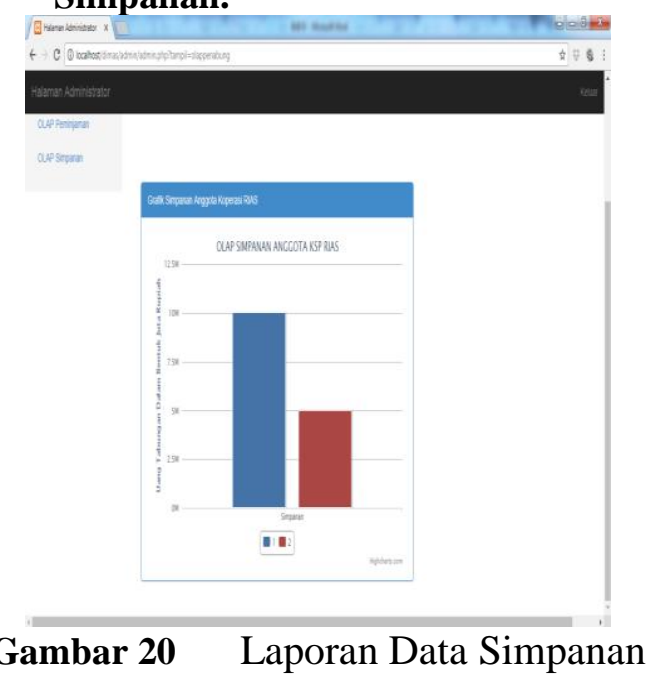

\section{SIMPULAN}

Setelah melalui proses pembangunan dan melihat dari pengujian Aplikasi OLAP (Online Analitycal Processing) Simpanan dan Pinjaman Anggota Pada Koperasi KSP Rias Musi Rawas, maka dapat diambil kesimpulan sebagai berikut:

1 Dengan adanya aplikasi ini dapat memudahkan pihak manajemen KPS Rias dalam struktur penyajian data simpanan dan pinjaman anggota, yang kemudian data tersebut akan mudah di analisis, dengan tujuan mendapatkan 
informasi untuk kebutuhan bisnis yang startegis.

2 Aplikasi dinilai sudah cukup membantu dalam hal analisa untuk memantau perkembangan simpanan dan pinjaman pada Koperasi Simpan Pinjam (KSP) Rias.

\section{SARAN}

Dari kesimpulan yang dijabarkan di atas, penulis menngusulkan saran - saran yang dapat dijadikan pertimbangan atau masukan sebagai berikut :

1 Menambah kan fitur untuk android mobile agar aplikasi ini bisa lebih efisien lagi.

2 Menambahkan fitur lain yang membuat OLAP ini maksimal untuk digunakan

3 Melampirkan informasi yang berhubungan dengan bunga simpan maupun pinjaman

\section{DAFTAR PUSTAKA}

[1] Andi, 2016, Membuat Web ECommerce dengan Adobe Dreamweaver CS5.5, Penerbit Wahana Komputer, Semarang

[2] Bin Ladjamudin Al Bahra, 2017, Analisa dan Desain Sistem Informasi, Penerbit Graha Ilmu, Yogyakarta

[3] Elvira Yolanda, 2018, Perancangan Aplikasi E-Commerce Berbasis Web Pada Pempek Rendy.

[4] Faisal S.Si, 2017. Aplikasi Berbasis Web dengan PHP dan MySQL, Yogyakarta.

[5] Irsyad Purdiantono, dan Achmad Wahid, 2018, Aplikasi CMS Ecommerce Penjualan Berbasis WAP Dengan Menggunakan PHP dan MySQL Di Toko Miulan Hijab Semarang.
[6] Kristanto Andri, 2018, Perancangan Sistem Informasi dan Aplikasinya, Penerbit Gava Media, Klaten

[7] Kodir Abdul 2019, Pengenalan Sistem Informasi, Penerbit Andi, Yogyakarta

[8] Lagiono 2017 Pola Implementasi Jejaring Sosial Facebook Sebagai Media Dalam Pembelajaran. Perkembangan teknologi 